\title{
酸化ニッケルーシリカーアルミナ触媒によるオレフィン 重合反応におけるベンゼン誘導体の溶媒および毒効果*
}

\author{
高橋 邦昌**, 浅野 真**, 米田 徳彦**, 大塚 博** \\ Oligomerization of Ethylene and Propylene with a Nickel Oxide-Silica-Alumina \\ Catalyst in the Presence of Benzene Homologues*
}

by Kunimasa Takahashi**, Makoto Asano**, Norihiko Yoneda** and Hiroshi Ohtsuka**

Summary : Oligomerization of ethylene and propylene on a nickel oxide-silica-alumina catalyst (NiOSA) was studied in the presence of benzene homologues.

In a series of experiments, benzene homologues were used as solvent. The reaction conditions were as follows : catalyst : $\mathrm{Ni}$ content of $\mathrm{NiO}-\mathrm{SA} 7.5 \mathrm{wt} 96$, amount used for a run $3.0 \mathrm{~g}$, feed : ethylene or propylene 1.0 mole; solvent volume : $30 \mathrm{ml}$, reaction temp. for ethylene $30^{\circ} \mathrm{C}$, for propylene $80 \sim 120^{\circ} \mathrm{C}$, reaction time : for ethylene $30 \mathrm{~min}$, for propylene $2 \sim 3 \mathrm{hr}$, stirring : $70 \mathrm{k} . \mathrm{p} . \mathrm{m}$.

In the presence of benzene homologue solvent, the activity of both olefins decreased rapidly in the following order :

$\mathrm{Cl}-\mathrm{B}>\mathrm{B}>\mathrm{T}>p-\mathrm{X}>o-\mathrm{X}>m-\mathrm{X}$.

On the other hand, the dimer selectivity increased with the decrease of olefin reactivity.

In another series of experiments, small amount of xylenes $(0.5 \sim 5.0 \mathrm{~g})$ was added to a mixture of the catalyst and solvent iso-octane in order to observe the poisoning effect of xylenes. In these cases, high dimer selectivity was maintained without losing high olefin activity. For example, when $0.5 \mathrm{~g}$ of $p-\mathrm{X}$ was added to $3.0 \mathrm{~g}$ of $\mathrm{NiO}-\mathrm{SA}$ and $30 \mathrm{ml}$ of iso-octane, $75 \mathrm{wt} \%$ of propylene conversion and $83 \mathrm{wt} \%$ of dimer yield (based on oligomer) were obtained.

Olefin oligomerization on NiO-SA was also observed to be poisoned by a small amount of ethanol. In this case, however, it was impossible to obtain a high yield of oligomers of high dimer selectivity.

It is suggested that the different poisoning behaviors of ethanol and xylenes are due to the difference in their electron donor strength. According to the experimental results shown in this paper, the weak acid sites produced by the addition of $\mathrm{NiO}$ to $\mathrm{SA}$ are considered to selectively promote the dimerization of olefns. These weak acid sites may not be so strongly poisoned by weak electron donors as xylenes. But they may be fatally poisoned by strong electron donors such as ethanol.

\section{1 緒言}

酸化ニッケルーシリカーアルミナ触媒（以下 $\mathrm{NiO}-\mathrm{SA}$ と略記） が通常の固体磼触媒とは異なるオレフィン重合特性をもつこと は広く知られている。すなわち, 小泉らは NiO-SA のエチレ ン重合能がプロピレン重合能よりも高いことを見いだし, 両オ レフィンとも低次重合体が選択的に生成されることを見いだし だ。また尾崎らはアルコール類および一酸化炭素被毒酸化二 ッケルー白土触媒によるエチレン重合実験の結果から，反忘点 と吸着点の存在を示唆した2)。また重水素交換酸化ニッケルーシ リカ触媒のオレフィン重合区応を研究し，オレフィン二量化は 酸点と低原子価ニッケル点の二元機構で進むとしだ)。今井ら も $\mathrm{NiO}-\mathrm{SA}$ のオレフィン重合反応を研究し, 酸化ニッケルを 担持する結果生成した酸点がエチレンい，プロピレンが を通し ての活性点であるとした。そして NiO-SA のプロピレン重合

* 昭和 46 年 6 月 14 日受理

** 北海道大学工学部応用化学科(札沅市北13条西 8 丁目) Department of Applied Chemistry, Faculty of Engineering, Hokkaido University (West 8 , North 13, Sapporo)
機棈としてシクロブタン誘導体説を提唱しだ5。佐野らは $\mathrm{NiO}$ -SAの表面構造を研究し, $\mathrm{NiO}$ 担持によって従来は強酸点ばか りであった SA の酸強度分布が変わり，妈酸点量が $50 \%$ 增す ことを報告した。また，NiO-SA のプロピレン重合は Lewis 酸点と $\mathrm{NiO}$ の活性酸素 (塩基点) の二元機棈によるとした Clark らはプロピレン重合の結果から Carbonium Ion 説が適 用しうるとしたフ。著者らもさきにプロピレン重合の結果に基 づいて Clark らの説が適用しうるとしだ)。またエチレンとプ ロピレンの共重合実戨の結果から， NiO-SA には SA に由来 する usual active sites と $\mathrm{NiO}$ 添师に由来する special active sites が共存する叮能性を示唆しだ。

著者らは本報で，ベンゼン誘乳体を NiO-SA の溶媒に用い るとエチレンおよびプロピレン重合能がベンゼン㻴の $\pi$ 電子密 度の增加によって䫓著に抑制されること，またこれらを触媒毒 に用いると高いオレフィン重合能を保って二量体選択率（生成 オリゴマーに占める二望体留分の㓶合）が増加することを報告 する。そして, ベンゼン誘導体被䔦 NiO-SA とエタノール被 毒 NiO-SA のオレフィン重合能を比較した結果， NiO-SA の酸点のうち,ごく少量のベンゼン誘導体程度の弱塩基性物斦 
では被毒されない弱酸点がエチレンおよびプロピレンの二量化 反応を支配していると結論した。

\section{2 実験方法}

\section{1 触媒と試薬}

NiO-SA の調製および烇成法とエチレンおよびプロピレン の純度は前報》に示した。な扰，触媒の $\mathrm{Ni}$ 担持量は $7.5 \mathrm{wt} \%$ であった。イソオクタン、シクロヘキサンおよびモノクロルベ ンゼンは市販特級品をそのまま用いた。ベンゼンは製鉄化学 （姝）製を $\mathrm{CaCl}_{2}$ で脱水し，蒸留によって再精製して用いた。 トルエンは市販特級品を， $o-, \quad m-$ および $p$-キシレンは日本 瓦斯化学工業 (株) 製をベンゼンと同じ精製操作をした後用い た。

\section{2 実験}

反応器として上下かくはん式オートクレーブ（内容䅡 300 $\mathrm{m} l$ ) を用いた。溶媒と触媒を所定量オートクレーブに充てん し, 乾燥空素ガスで $10 \mathrm{~kg} / \mathrm{cm}^{2} \cdot \mathrm{G} 八 2$ 回内部空気を圈換した。 ベンゼン誘導体を溶绦として用いるときはただちにオレフィン (1 mol) を導入して所定温度と時間で反応を行なった。ベンゼ ン誘導体を毒として用いるときは, 触媒・㫱・インオクタン混 合物を室温で 2 時間かきまぜた後にオレフィンを導入し, 重合 反忘を開始した。

\section{3 生成物分析}

前報》 に準じた方法で ガス成分と沸点 $100^{\circ} \mathrm{C}$ までの液成分 を分取した。

ガス成分の分析はイソキノリン・カメライトカラム゙によっ た。液成分の一部は水素添加し9，オレフィン組成と同時に液 生成物（人キセン類）の炭素鎖骨格存在量を決定した。分析に は日立 K-23 型 G.C. [F.I.D., Golay Column (squalane 45 m)]を用いた。

質量分析計は日立 RMU-6 E 型を用いた。

\section{3 実験結果}

\section{1 ベンゼン誘㮏体を溶媒としたエチレン重合}

モノクロルベンゼン (Cl-B), ベンゼン (B), トルエン ( $\mathrm{T})$, $p$-キシレン $(p-\mathrm{X}), o$-キシレン $(o-\mathrm{X}), m$-キシレン $(m-\mathrm{X})$ および脂肪族パラフィンとしてイソオクタン $(i-O), \pi$ 電子を むたない六員環化合物としてシクロヘキサン (C.H.) をそれぞ れ溶媒として NiO-SA のエチレン重合能を䘽察した。

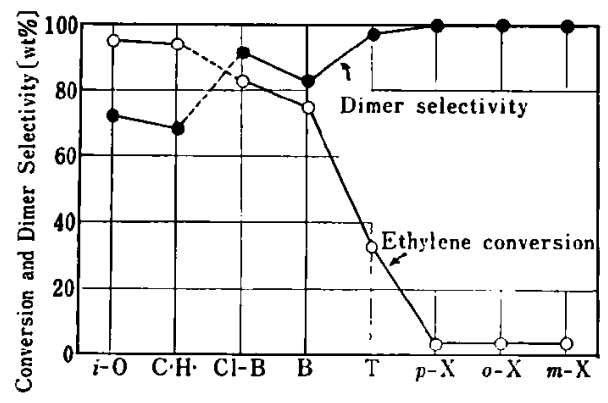

Reaction conditions : $30^{\circ} \mathrm{C}, 30 \mathrm{~min}$ and $70 \mathrm{k.p.m}$. Catalyst : $\mathrm{Ni}=7.5 \mathrm{wt} \%, 3.0 \mathrm{~g}$, Solvent : $30 \mathrm{ml}$, Ethylene : $1.0 \mathrm{~mol}$.

Fig. 1. The Effect of Solvents on Ethylene Oligomerization

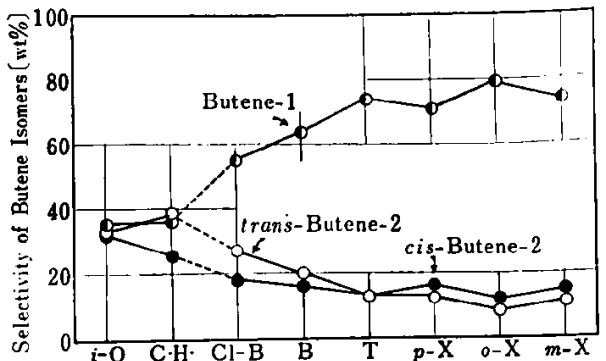

Fig. 2 The Effect of Solvents on Ethylene Oligomerization -Isomer Distribution of Ethylene Dimers-

得られた結果を実験条件とともに Fig. 1 および Fig. 2 に 示した。

Fig. 1 に示すごとく，イソオクタンおよびシクロへキサン のエチレン転化率は $95 \mathrm{wt} \%$ 前後であり, 画者の差はほとんど 認められなかった。一方, ベンゼン誘導体の溶媒効果は明らか に認められ，NiO-SA のエチレン転化率は，

$\mathrm{Cl}-\mathrm{B}>\mathrm{B}>\mathrm{T}>p-\mathrm{X} \geqq 0-\mathrm{I} \geqq m-X$

の順で減少した。 $p-\mathrm{X}, o-\mathrm{X}$ および $m-\mathrm{X}$ のエチレン転化率は 約 $4 \mathrm{wt} \%$ であり， Cl-B，B，T およびXの間に認められた大 きな差翼はなかった。

二量体選択率はエチレン框化率の娍少とは逆に增加し，Xで は $100 \mathrm{wt} \%$ となった。

ブテン-1 選択率（ブテン異性体中のブテン-1 含䭪）はエチ レン転化率の挙動と類似の㑯向を示した（Fig. 2)。またブテ ン-2の異性体比 (cis/trans) は Cl-B, B, T では 1 以下である が，Xでは1を越えた。この傾向はエタノール被毒 NiO-SA では認められない現象である。

\section{2 ヘンゼン誘導体を溶媒としたプロビレン重合}

エチレン重合と同じ溶媒を用いて NiO-SA のプロピレン重 合能の変化を観察した。得られた結果を, 実跧条件とともに Fig. 3 および Fig. 4 に示した。

溶媒としてイソオクタンおよびシクロへキサンを用いた NiO-SA のプロピレン転化率は約 $70 \mathrm{wt} \%$ で両者の差は認め られなかった (Fig. 3)。溶媒にベンゼン誘遵体を用いると NiO-SA のプロピレン転化率はエチレン重合の場合と同じ娍 少傾向を示し,

$\mathrm{Cl}-\mathrm{B}>\mathrm{B}>\mathrm{T}>p-\mathrm{X} \geqq o-\mathrm{X} \geqq m-\mathrm{X}$

の順で減少した。

二量体選択率は転化率と同じ隇少傾向を示した。

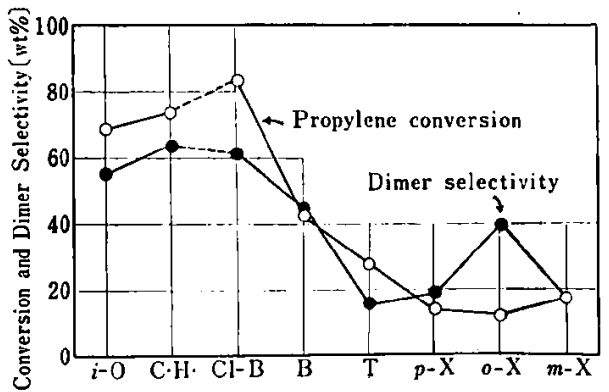

Reaction conditions : $80^{\circ} \mathrm{C}, 2 \mathrm{hr}$ and 70 k.p.m Catalyst : $\mathrm{Ni}=7.5 \mathrm{wt} \%, 3.0 \mathrm{~g}$, Solvent : $30 \mathrm{~m} l$, Propylene : $1.0 \mathrm{~mol}$.

Fig. 3 The Effect of Solvents on Propylene Oligomerization 
高橋，浅野，米田，大第：酸化ニッケルーシリカーフルミナ触媒によるオレフィン重合反応におけるベンゼン誘導体の溶媒および毒効果 997

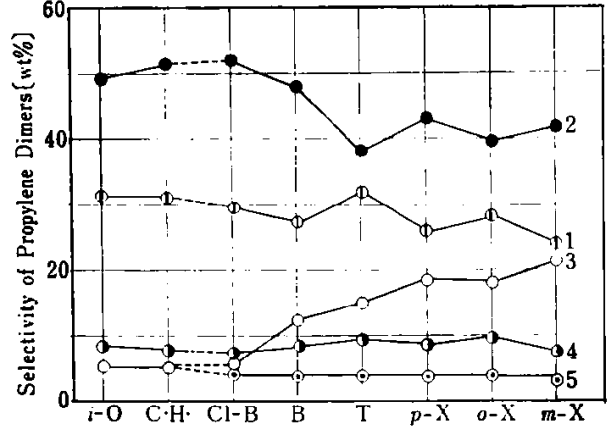

1 : Hexene-1,2,3 2: cis-, trans-4-Methyl Pentene-2

3 : 4-Methyl pentene-1 $4: 2$-Methyl pentene-1,2

5 : 2,3-Dimethyl Butene-2

Fig. 4 The Effect of Solvents on Propylene Oligomerization -Isomer Distribution of Propylene Dimers-

Fig. 4 に二筮体組成を示した。プロピレン転化率の娍少と ともに 4-メチルペンテン-1の選択率が增し, 刘照的に cis-, trans-4-メチルペンテン-2 のそれが減少した。他の成分に変 化は認められなかった。

3.3 キシレン類を触媒毒としたェチレンおよびプロピレン 重合

3.1 および 3.2 でキシレン類を溶媒として用いた NiO-SA のエチレンおよびプロピレン重合能は著しく阻害されることを 示した。本節では $p-, o-$ および $m$-キシレンを触媒瑇として それぞれ 0.5 5.0 g NiO-SA・イソオクタンに添加してェチレ ンの重合およびプロピレンの重合を行なった。
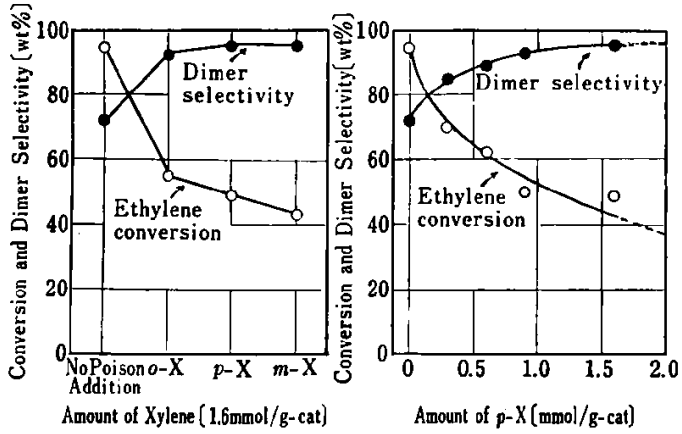

Reaction conditions : $30^{\circ} \mathrm{C}, 30 \mathrm{~min}$ and 70 k.p.m. Catalyst : $\mathrm{Ni}=7.5 \mathrm{wt} \%, 3.0 \mathrm{~g}$, Solvent : $i$-Octane $30 \mathrm{ml}$ (with xylene), Amount of xylene added : 0.3 1.6 $\mathrm{mmol} / \mathrm{g}$-cat., Ethylene : $1.0 \mathrm{~mol}$.

Fig. 5 The Effect of Xylene Addition as a Catalyst Poison on the Activity of NiO-SA for Ethylene Oligomerization

エチレンの重合結果を Fig. 5 に実験条件とともに示した。 キシレン類 $(0.3 \sim 1.6 \mathrm{mmol} / \mathrm{g}$-cat.) の添加によりエチレン転 化率は $o-\mathrm{X}>p-\mathrm{X}>m-\mathrm{X}$ の順で減少し, 溶媒効果同樣毒効 果む見いだされた。しかし，エチレン転化率はこれらを溶媒と して用いたときは約 $4 \mathrm{wt} \%$ であったのに対し 50〜 70 wt $\%$ 前 後の值を示した。一方, 二量体選択率は無被毒 NiO-SA(Fig. 1 のインオクタン参照) では約 70 wt 96 であるのに対し， 85 〜95 wt\% と增加した。すなわち, キシレン類を強媒毒に用い ると NiO-SA のエチレン重合能をある程度保持したまま二量 体選択率を高めることができることがわかる。なお，ブテンー1 選択率は 71〜76 wt％ であった。

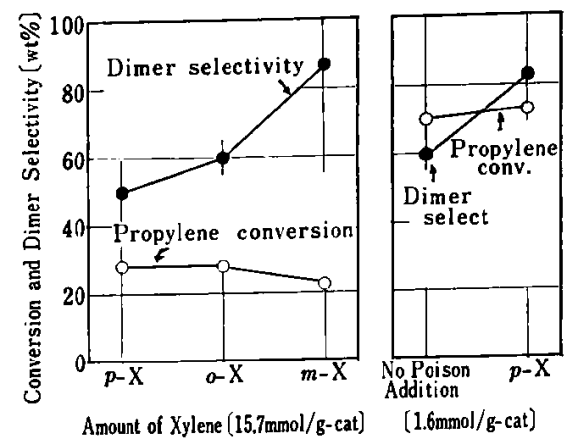

Reaction conditions : $80^{\circ} \mathrm{C}, 2 \mathrm{hr}$ and 70 k.p.m., Catalyst : $\mathrm{Ni}=7.5 \mathrm{wt} \%, 3.0 \mathrm{~g}$, Solvent : $i$-Octane 30 $\mathrm{m} l$ (with xylene), Amount of xylene $: 15.7 \mathrm{mmol}$ $/ \mathrm{g}$-cat. and $1.6 \mathrm{mmol} / \mathrm{g}$-cat., Propylene : $1.0 \mathrm{~mol}$.

Fig. 6 The Effect of Xylene Addition as a Catalyst Poison on the Activity of NiO-SA for Propylene Oligomerization

Fig. 6 に $15.7 \mathrm{mmol} / \mathrm{g}$-cat. の $o^{-}, p$ - 扔よび $m$-X を触 媒少とした場合と $1.6 \mathrm{mmol} / \mathrm{g}$-cat. のp-X を触媒毒とした場 合の NiO-SA のプロピレン重合能を観察した結果を実験条件 とともに示した。なお，溶媒にイソオクタンを用いたが，その 望は毒とともで $30 \mathrm{~m} l$ とした。

$15.7 \mathrm{mmol} / \mathrm{g}$-cat. のキシレンを加えたときの NiO-SA のプ ロピレン転化率は $23 \sim 29 \mathrm{wt}$ \% であり, 枟化率は $p-\mathrm{X} \geqq o-\mathrm{X}$ $>m-\mathrm{X}$ の順で減少する傾向を示した。また, 二量体選択率は $p-\mathrm{X}<o-\mathrm{X}<m-\mathrm{X}$ の順であり， $m-\mathrm{X}$ では約 $85 \mathrm{wt}$ \% に達し た。

$1.6 \mathrm{mmol} / \mathrm{g}$-cat. の $p$-X を加えたとき, プロピレン転化率 は 75 wtg であり，無被毒 NiO-SA の場合と変化はなかっ た。一方, 二量体選択率は約 83 wt $\%$ に達した。

いずれの場合でも，プロピレン二量体の炭素鎖骨格は 2,3 ジメチルブタン型，2-メチルペンタン型捕よび n-ヘキサン型 の3 種類であった。また二量体選択率が増しても二量体のオレ フィン組成には変化が認められなかった。

\subsection{NiO-SA によるプロビレン高重合物の質量分析}

ベンゼン誘導体を溶媒とした NiO-SA のプロピレン重合生 成物のうち三量体以上の高沸点生成物の炭素数分布を質量分析 によって求めた。得られた結果を実験条件とともに Table 1 にまとめた。

高沸点生成物を容易に分析できるように反応条件を $120^{\circ} \mathrm{C}$, $3 \mathrm{hr}$ と通常の条件 $\left(80^{\circ} \mathrm{C}, 2 \mathrm{hr}\right)$ 上りも過酷にした。得られた 生成物を蒸留によって沸点 $100^{\circ} \mathrm{C}$ までの成分と $100^{\circ} \mathrm{C}$ 以上の 成分に分離した。 $100^{\circ} \mathrm{C}$ まの成分は常法によって組成と炭素 鎖骨格存在量を定量し，二量体選択率を求めた。100 $\mathrm{C}$ 以上の 成分は日立 RMU-6 E 型質量分析計によって質量分布を求め た。得られたデータを, ASTM Designation：D 2424-67, Standard Method of Test for Hydrocarbon Types in Propylene Polymer by Mass Spectrometry の計算法と付表に従 って嵃算し，オレフィンの炭素数分杯を求めた。なお，分析機 器が異なるので $100^{\circ} \mathrm{C}$ 以上の成分中に含まれるオレフィン, パラフィン，アルキルベンゼンおよびアルケニルベンゼン等の 定量值には信頼性がないので削除した。 
Table 1 Mass Spectrometric Analysis of Propylene Oligomers Produced by NiO-SA

Reaction conditions : $120^{\circ} \mathrm{C}, 3 \mathrm{hr}, 70 \mathrm{k}$. p.m.

Catalyst : $\mathrm{Ni}=7.5 \%, 3.0 \mathrm{~g}$

Propylene : $1.0 \mathrm{~mol}$

Mass spectrometer : Hitachi RMU-6 E Type

\begin{tabular}{c|c|c|c|c|c}
\hline Solvent & C.H. & $i-\mathrm{O}$ & $\mathrm{B}$ & $\mathrm{T}$ & $p$-X \\
\hline $\begin{array}{c}\text { Propylene Conversion } \\
\text { (wt\%) }\end{array}$ & 89.9 & 89.9 & 83.7 & 74.7 & 57.0 \\
\hline $\begin{array}{c}\text { Dimer Selectivity } \\
\text { (wt\%) }\end{array}$ & 41.9 & 48.2 & 47.2 & 49.8 & 76.2 \\
\hline
\end{tabular}

Carbon Number Distribution of Propylene Oligomers Boiling Higher Than $100^{\circ} \mathrm{C}$.

\begin{tabular}{c|c|c|c|c|c}
\hline Sarbon Number & C.H. & $i-\mathrm{O}$ & $\mathrm{B}$ & $\mathrm{T}$ & $p-\mathrm{X}$ \\
\hline 6 & 0 & 35.0 & 26.9 & 25.2 & 29.7 \\
7 & 0 & 0 & 0 & 0 & 0.1 \\
8 & 0 & 0 & 0 & 0 & 0 \\
9 & 50.2 & 46.5 & 57.2 & 40.6 & 56.8 \\
10 & 1.0 & 0 & 0 & 0 & 0 \\
11 & 0.8 & 0 & 0 & 1.0 & 0 \\
12 & 39.9 & 18.5 & 15.0 & 25.5 & 13.4 \\
13 & 0.3 & 0 & 0 & 0 & 0 \\
14 & 0.3 & 0 & 0 & 0 & 0 \\
15 & 7.6 & 0 & 0.9 & 7.8 & 0 \\
16 & 0 & 0 & 0 & 0 & 0 \\
17 & 0 & 0 & 0 & 0 & 0 \\
18 & 0 & 0 & 0 & 0 & 0 \\
\hline
\end{tabular}

$120^{\circ} \mathrm{C}, 3 \mathrm{hr}$ とい5条件下ではシクロへキサンおよびイソオ クタン溶媒のときプロピレン転化率は約 $90 \mathrm{wt} \%$ に達した。ま た B, T および $p-\mathrm{X}$ でも転化率は $80^{\circ} \mathrm{C}, 2 \mathrm{hr}$ の場合の $2 \sim 3$ 倍に達した (Fig. 3 参照)。しかし Fig. 3 同様溶媒効果は明 らかであり,プロピレン転化率は $\mathrm{B}>\mathrm{T}>p-\mathrm{X}$ の傾向を示し た。また二量体選択率は $p-\mathrm{X}>\mathrm{T}>\mathrm{B}$ の順であり， Fig. 3 の場合の傾向とは異なっていた。

$100^{\circ} \mathrm{C}$ 以上の生成物の炭素数分布はシクロへキサン溶媒で多 少の乱れが認められるが，ほほ 3 の倍数分布を示した。また重 合度は最高五量体であり，二〜三量化が主反応であった。また 分取除去されたはずのへキセン留分が $30 \mathrm{wt} \%$ 前後含まれて

おり，蒸留が完全でないことが明らかとなった。

3.5 エタノール (以下 EtOH と略記) 被毒 NiO-SA によ るオレフィン重合

水, アルコールおよびエーテルが NiO-SA のエチレン重合 能を抑制することは，尾崎によって報告された $\mathrm{EtOH}$ 被毒 NiO-SA のオレフィン重合能と二量体選択率およ び二量体組成の変化を钼察した。得られた結果を Fig. 7〜10 に示した。

Fig. 7 および Fig. 8 に示すように，EtOH 被瑇 NiO-SA のエチレンおよびプロピレン重合能は $\mathrm{EtOH}$ 量とともに低下 し， $0.5 \sim 0.7 \mathrm{mmol} \mathrm{EtOH} / \mathrm{g}$-cat. で消失した。またオレフィ ン重合能の減少とは逆にオレフィン二量体選択率は增加し, 触 媒の致死条件付近で $100 \mathrm{wt} \%$ に達した。

Fig. 9 にエチレン二量体組成を示した。プテン-1 選択率は $0.3 \mathrm{mmol} \mathrm{EtOH} / \mathrm{g}$-cat. で $80 \mathrm{wt} \%$ に達した。しかし, それ 以上の $\mathrm{EtOH}$ 量では逆に減少した。一方, ブテン-2 の異性
体比 cis/trans は $0.3 \mathrm{mmol} / \mathrm{g}$-cat. で 1 となり，以降一定と なった。

Fig. 10 に EtOH 量の増加に伴うプロピレン二量体組成の 変化を示した。 $\mathrm{EtOH}$ 龔の增加によって 4-メチルペンテン-1 の選択率が増加し, 相対的に cis-, trans-4-メチルペンテン-2 選択率が減少した。他の暴性体選択率は $\mathrm{EtOH}$ 量に対し，ほ ぼ一定傎を保った。

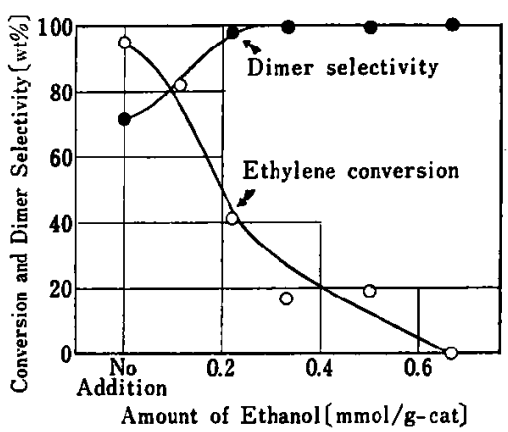

Reaction conditions : $30^{\circ} \mathrm{C}, 30 \mathrm{~min}$ and 70 k.p.m. Catalyst $: \mathrm{Ni}=7.5 \mathrm{wt} \%, 3.0 \mathrm{~g}$, Solvent : $i$-Octane $30 \mathrm{ml}$, Ethylene : $1.0 \mathrm{~mol}$.

Fig. 7 The Effect of Ethanol Addition as a Catalyst Poison on the Activity of NiO-SA for Ethy* lene Oligomerization

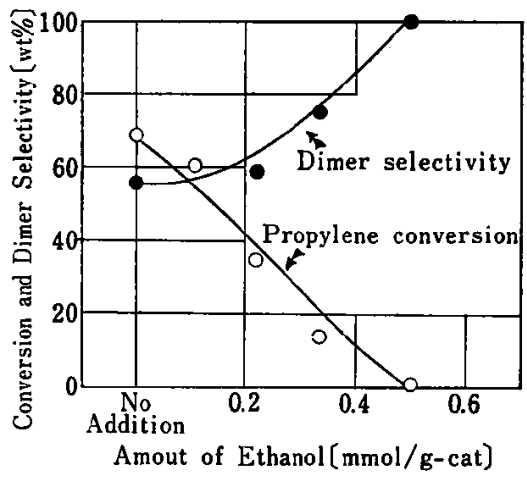

Reaction conditions : $80^{\circ} \mathrm{C}, 2 \mathrm{hr}$ and 70 k.p.m. Catalyst : $\mathrm{Ni}=7.5 \mathrm{wt} \%, 3.0 \mathrm{~g}$, Solvent : $i-$ Octane $30 \mathrm{ml}$, Propylene : $1.0 \mathrm{~mol}$.

Fig. 8 The Effect of Ethanol Addition as a Catalyst Poison on the Activity of NiO-SA for Propylene Oligomerization

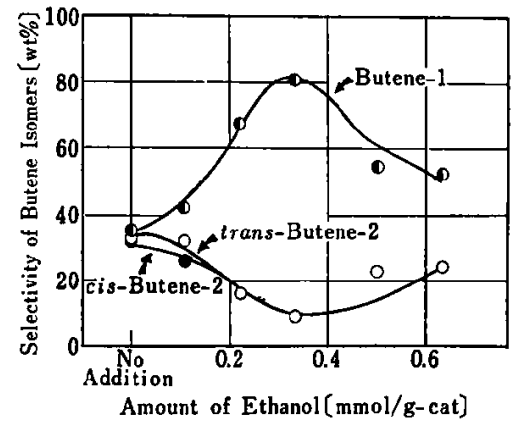

Fig. 9 The Effect of Ethanol Addition on Ethylene Oligomerization

-Isomer Distribution of Ethylene Dimers- 


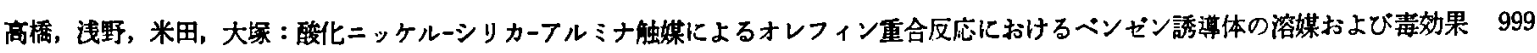

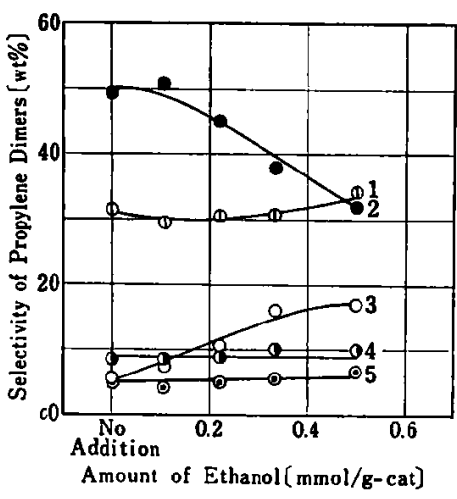

$1:$ Hexene-1,2,3 2 : cis-, trans-4-methyl pentene-2 3 : 4-Methyl pentene-1 4:2-Methyl pentene-1,2 5 : 2,3-Dimethyl butene-2

Fig. 10 The Effect of Ethanol Addition on Propylene Oligomerization - Isomer Distribution of Propylene Dimers-

\section{4 考察}

ベンゼン誘導体を溶媒もしくは触葉毒に用いた NiO-SA の オレフィン重合反応の結果について考察した。

1) ベンゼン䄈導体の活性抑制の程度を無被毒 NiO-SA の 活性と比較するための基準溶媒として， $\pi$ 電子を持たないイン オクタンおよびシクロへキサンの性能を比較した。

Fig. 1, 3 および Table 1 の結果より, 両溶媒下での $\mathrm{NiO}$ -SA のオレフィン重合能がほぼ同じであることがかかる。両 者の相違点は Table 1 の質量分析の結果に見られる。すなわ ち, プロピレンオリゴマーの炭素数分布がイソオクタンでは 3 の倍数であるのに対し, シクロヘキサンでは 10〜14 の炭素数 のオレフィンが微量存在する。またシクロへキサンを溶媒とし た重合反応の二量体選択率はイソオクタンのそれよりも低い。

以上の結果に基づき， $\mathrm{NiO}-\mathrm{SA}$ の活性を測定する基準溶媒 としてインオクタンを用いた。

2）ベンゼン誘導体を溶媒に用いると NiO-SA のオレフィ ン重合能が抑制される (Fig. 1,3 および Table 1)。

Brown らは $\mathrm{HCl}$ とベンゼン誘導体との間の $\pi$ 錯体生成能 は圈換基によって異なり， $\mathrm{Cl}-\mathrm{B}(0.87)<\mathrm{B}(1.00)<\mathrm{T}(1.51)$ $<p-\mathrm{X}(1.64)<o-\mathrm{X}(1.85)<m-\mathrm{X}(2.07)$ なる相対的序列が成 立することを報告した ${ }^{10 \%}$ 。

この序列は Fig. 1，3 および Table 1 の NiO-SA のオレ フィン重合能の低下傾向と一致する。しかし, Fig. 3 に示す よちに NiO-SA のプロピレン転化率が Cl-B(83), B(43)， $\mathrm{T}(28), \mathrm{X}(12 \sim 18)$ と溶媒の異なるごとに半減し, エチレン重 合の場合も同様の傾向を示すのに対し， $\pi$ 錯体生成能にはこれ ほどの差はない。この事実はべンゼン環の $\pi$ 錯体生成能が少し 增加して弱い活性点 (弱酸点) との結合力が増すと NiO-SA のオレフィン重合能の阻害が著しくなることを意味する。

一方，Fig. 5 および Fig. 6 に示すよ5にキシレン類を触 媒毒として用いると，毒量が少ないときはオレフィン重合能は ほとんど阻害されず，無被毒 NiO-SA に近い転化率を保った まま二量体の選択率を高めることができる。すなわち，キシレ ン類はオレフィン三量化以上の高重合反応を促進する重合活性 点 (強酸点) を選択的に被毒する。しかし，キシレン類が溶媒
として大過剩量存在するときは強酸点だけへの選択的吸着が不 可能であり，オレフィン二量化反応に活性な弱酸点る被覆され る結果オレフィン重合能が低下する。しかし, ベンゼン誘導体 と NiO-SA の弱酸点との結合力は強固ではないので, Table 1 に示すように高い反応温度では切断され， B， T, X ともに 高いプロピレン枟化率と二量体選択率を同時に得ることが可能 となる。

澌量分析の結果は，NiO-SA によるプロピレン重合反応で は SA による類似条件下でのプロピレン重合反心にみられる オレフィン炭素数のばらつき（生成物の解重合反応による）が 生じいこと，重合が主として二〜三量化で停止していること を示す。この現象はイソオクタンとベンゼン誘導体でみられ， $\pi$ 電子には関係がない。っってこれらの事実は SAに NiO を 担持することで解重合反応や高重合反応に有効な SA の強酸 点 (固体りん酸触媒, 澹硫酸および $\mathrm{BF}_{3}-\mathrm{H}_{2} \mathrm{O}$ ではプロピレン の三〜四量化や生成物の解重合が容易に進むことより強酸点と 考えられる) の強度が弱められていることを示唆する。実際， 佐野らは $\mathrm{NiO}$ の担持によって $\mathrm{SA}$ の強酸点が減じ, 弱酸点が 509以上増加する事実を見いだしだす。なお， $\mathrm{NiO} の$ 添加と酸 点強度の減少との関連については, NiO-SAに拈いて酸点とと もに重要な活性点と考えられる塩基性点の性質の研究の報告"1 において詳細な検郡を加える予定である。

な㧍，質量分析の結果は沸点 $100^{\circ} \mathrm{C}$ までの蒸留によってす べてのへキセン留分を分取することは不可能であり，高沸点才 レフィン中には $30 \%$ 前後のへキセン留分が残存することを示 す。よってすべてのプロピレン重合実験を通して実際の二量体 選択率は蒸留によって得られた值よりも常に高いことがわか る。一方, プロピレン反応量が少なくかつ溶媒の沸点が $100^{\circ} \mathrm{C}$ 以上のときは，高沸点留分中に残存するへキセン絶対量が多く なるため，見かけの二量体選択率は著しく減少するのは明らか である。したがって，ベンゼン誘導体を溶媒としたプロピレン の重合反応で二量体選択率が転化率とともに減少する（Fig. 3）のは，上記原因による必然的誤差と考えられる。よって㬰 㗫には心゙ンゼン諉導体を溶媒としたプロピレン重合 $\left(80^{\circ} \mathrm{C}, 2\right.$ hr）でむ，毒として用いた場合と同様，二量体選択性は変化せ す，重合能のみが影響をうけるものと推定される。

3） $\mathrm{E} \mathrm{tOH}$ もキレン類同様 NiO-SA のオレフィン重合能 を阻害する。しかし $\mathrm{EtOH}$ とキシレン類とでは NiO-SA に 対する毒作用の様式が明らかに異なっている。

$\mathrm{EtOH}$ を 0.5 0.7 mmol/g-cat. 添加すると NiO-SA のオ レフィン重合能はほとんど 消失し，オレフィン二量体は 100 wtg6 に達する (Fig. 7 および Fig. 8)。しかし，キシレン類 の毒効果として認められたような高いオレフィン転化率を保。 て二量体選択率を高めること(Fig. 5 および Fig. 6)はできな い。この両者の毒作用の相違は lone pair 電子供与体と $\pi$ 電子 供与体の電子供与力の相違によると考えられる。すなわち，鍵 谷らは液状有機化合物の電子供与性の尺度を研究し，ベンゼン 誘導体等の $\pi$ 電子とェーテル,ピリジン等の lone pair 電子と ではその電子供与力に 5 10倍の差があることを報告した ${ }^{12) 。 ~}$ EtOH は lone pair 電子供与体であり，その電子供与能が強 いため NiO-SA に少量加えられた場合, 強酸点に選択的に吸 着することなく弱酸点にも吸着する可能性が高いと考えられ 
る。したがって, 毒量の増加とともに強酸点が被毒されて二量 化反応が支配的になる。しかし，同時に二星化反応に有効な弱 酸点も被毒されるためオレフィン冓合能自体も減衰していく。 一方, キシレン類のような $\pi$ 電子供与体はその電子供与能が弱 く, NiO-SA に少量加えられたとき, 強酸点から選択的に吸 着し, 弱酸点は生き残ると考えられる。

4） NiO-SA の特異な触媒能として，温和な条件下で高い エチレン重合能を有すること”，拉よびプロピレン二量体中に SA による重合では数名の存在しか認められない $n$-ヘキサン 型炭素鎖骨格オレフィンが約 $30 \mathrm{wt}$ 名 存在するこどなどが知 られている。

Fig.4およびFig. 10 に示すごとく，NiO-SA をベンゼン誘 導体で被毒した場合も EtOH で被毒した場合も，プロピレン 二量体組成の変化の傾向はまったく同じである。すなわち，プ ロピレン転化率の減少と並行して 4-メチルペンテン-1 選択率 が増し, その分だけ cis-, trans-4-メチルペンテン-2 選规率 が減っている。一方, 被毒物質の種類によらず二量体炭素鎖骨 格の存在比は一定であり，2,3-ジメチルブタン型（4８ wt \%)，2-メチルペンタン型 (62〜68 wt\%) および $n$-ヘキサン 型 (27 32 wt \%) の 3 種類の骨格が存在する。また，いずれ の実験でも 3-メチルペンタン型は $0.3 \mathrm{wt}$ \% 以下しか存在しな かった。

これらの事実は NiO-SA の酸点はプロピレン二量体の二重 結合を移動する異性化能はもつが, 炭素鎖骨格を変える異性化 能はほとんどもっていないことを示唆する。よって $\mathrm{NiO}-\mathrm{SA}$ の直鎖二量体の選択的生成は, その酸点の作用のみに基づくも のでないことは明らかである。

著者らは前埇"で, NiO-SA には usual active sites と special active sites とが存在するとして, エチレンープロピレン 共重合の反応機構を考えた。また NiO-SA は酸点とともにフ ェノール吸着点 (塩基点) が存在し, オレフィン重合能は両者 に支配されている可能性を発表した ${ }^{13)}$ 。

本報で得られた知見から，NiO-SA の usual active sites は 弱酸点でありここれが温和な条件での NiO-SA のオレフィン 二量化能を制御しているといえよう。

一方, special active sites が塩基点自身なのか, それとも塩 基点と弱酸点との協力触媒作用を special active sites の作用 としては握しているのかは疑問であり,さらに検討の余地があ る。

エチレン二量体組成も酸点被毒によって変化する。特に Fig. 2 に示すごとくキシレン類を溶媒とした重合では cis/trans 比 が 1 を越えるのに対し， Fig.9 に示すよらに EtOH 被毒で は最大 1 にとまるなど, 毒物質の電子供与能の大小によって挙 動が異なる。しかし，二量体組成は塩基点被毒でも変化するこ
と ${ }^{11)}$ エチレン重合能は塩基点に強く支配されていること帛な どから考えて, 上述の挙動を酸点強度との関連のみで説明する ことは若干問題がある。したがって，エチレン二量体組成の変 化はプロピレン二量体の炭素鎖骨格選択性の問題とともに，酸 塩基两機能触媒の観点から検討することが望ましいと考え，こ の見地から硎究を続行中である。

\section{5 結诿}

本報ではベンゼン誘遒体を溶媒および触媒毒に用いて $\mathrm{NiO}$ SA のオレフィン重合能と二量体生成能の変化を観察した。同 時に $\mathrm{EtOH}$ 被売 $\mathrm{NiO}-\mathrm{SA}$ のオレフィン重合能と二量体生成能 し観察した。その結果，キシレン類で被毒した NiO-SA では 高いオレフィン重合能を保持して高い二量体選択率をうること の可能なことを見いだした。そして SA に担持された $\mathrm{NiO} に$ 由来する弱酸点が NiO-SA のオレフィン二量化能を支配して い西と結論した。しかし，弱酸点も強酸点もそれぞれ単独では プロピレン二量体中の直鎖炭素鎖骨格を形成する能力はもたな いことを見いだした。したがって，前報に述べた，いわゅる usual active sites は弱酸点と考えられるが，直鎖型成分をつ くる能力があると推定される special active sites の本質につ いてはまだ十分に理解することはできなかった。しかし，これ が触媒上の塩基点と密接な関連があることは明らかなのて， special active sites が塩基点のみであるのか，あるいは塩基点 と酸点との協同作用を special active sites としては握してい るのかを明らかにするために研究を続行中である。

\section{参考文献}

1) Koizumi, M. et al., J. Osaka City Univ., 4, series C (1953).

2）斯波忠夫，尾崎 咊，日化， 74，295 (1954); 尾崎 萃, 75, 1 (1955); 尾崎 椊, 77, 100 (1957).

3) Kimura, K., Ozaki, A., J. Catalysis, 18, 271 (1970).

4) Uchida, H., Imai, H., Bull. Chem. Soc. Japan, 35, 995 (1962).

5) Imai, H., Hasegawa, T., Uchida, H., Bull. Chem. Soc. Japan, 41, 45 (1968).

6）佐野正勝，景山芳短，大塚俊郎，青村和夫，触媒（触媒討諭会予 稿), 13, 73 (1971).

7) Hogan, J.P., Clark, A. et al., Ind. Eng. Chem., 47, 752 (1955).

8）高橋邦昌，佐々木 治，青村和夫，大塚 博，北大工研究報告， 53, 201 (1969).

9) Takahashi, K., Yoneda, N., Ohtsuka, H., Bull. of Japan Petrol. Inst., 13, (1), 55 (1971).

10) Brown, H. C., Brady, J. D., J. Am. Chem. Soc., 74, 3570 (1952).

11）高橋邦昌，浅野 真，米田德彦，大塚 博，投稿予定。

12）角田裕三, 鋌谷 勤, 触媒 (触媒討論会予稿)，19，52 (1971).

13）高橋邦昌，西 秀埗，浅野 真，米田德彦，大塚 博，触媒（触 媒討論会予樀), 13, 77 (1971). 